\title{
Building Social Capital in the Digital Age of Civic Engagement
}

\author{
Lynn Mandarano', Mahbubur Meenar ${ }^{2}$, and Christopher Steins ${ }^{3}$
}

(S)AGE

\begin{abstract}
The use of digital technologies to enhance traditional public participation processes and to build a new form of a social capitaldigital social capital-is being embraced in a range of planning practices. This article presents a discussion of how the digital age is influencing public participation and its implications for building social capital. The article highlights critical concerns to consider when embracing Internet tools for civic engagement and when evaluating such practices. The authors conclude with a call for scholarly research to assess the constraints and opportunities presented by this emergent trend and comparative studies to traditional modes of public participation.
\end{abstract}

\section{Keywords}

public participation, social capital, civic engagement, social media, digital media, social network site, Internet

\section{Introduction}

We are living in the digital age, a period in which digital technologies serve as the infrastructure of our communications. The influence of information and communication technologies is perceptible in all spheres of life including governance, education, economy, and private lifestyles. As the availability of mobile computing devices such as PDAs, iPhones, and location-aware GPS-based systems has become increasingly useful over the several years, and the usage of wireless access to the Internet has dramatically increased throughout the United States, so has the ordinary citizen's expectation for quick and easy access to information. In short, we are becoming digital citizens; we are profoundly changing the way we live and interact with others.

In response to the increase in access to and widespread usage of digital technologies and Internet resources, governments are embracing the use of these tools to communicate with their constituents. The four forms of e-government include e-management, e-services, e-economy, and e-democracy (Goodspeed 2008). While all forms of e-government are relatively new and worthy of exploration, this article focus on e-democracy, the use of Internet tools to enhance traditional public participation processes and to build a new form of a social capital - digital social capital.

This article focuses on the concept of digital social capital, the process of building digital communities through planning practice, specifically public participation processes that embrace Internet tools. The article includes four sections: civic engagement and social capital, the influence of the digital age on communication, digital technologies in planning practice, and evaluating digital social capital in planning practice. The authors conclude with a discussion of the opportunities and constraints relevant to digital civic engagement and social capital as well as the need for scholarly research on the impacts of digital public participation on social capital and for comparative studies to traditional public participation.

\section{Civic Engagement and Social Capital}

Having an informed and active civic society was a goal of Thomas Jefferson and an element of Jeffersonian democracy that stressed the role of the common people not aristocrats in influencing government. When Alexis de Tocqueville visited America in the early nineteenth century, he was fascinated by how active Americans were in forming associations and how knowledgeable they were about local politics. Such participation in associations including, for example, education, recreational, professional, and religious organizations, is a useful barometer of community involvement (Putnam 2000). However, due to the dominance of systems and rational planning theories, which view planning practice as steeped in technical analyses and planners as technical experts, civic engagement was limited up until the mid-twentieth century.

Starting in the 1960s, a new school of thought emerged embracing the view of a planner "as not so much a technical

\footnotetext{
'Mandarano, Department of Community and Regional Planning, Temple University, Ambler, PA, USA

${ }^{2}$ Meenar, Center for Sustainable Communities, Temple University, Ambler, PA, USA

${ }^{3}$ Steins, Urban Insight, Los Angeles, CA, USA
}

Corresponding Author:

Mahbubur Meenar, 580 Meetinghouse Rd, Ambler, PA 19002, USA

Email: meenar@temple.edu 
expert ..., but more as a 'facilitator' of other people's views about how a town or part of a town, should be planned" (Taylor 1998, 161-2). This thinking led to dramatic changes in planning practice opening the door to public participation becoming a routine part of planning practice. Roberts (2004) outlines the history of citizen participation in planning practice, which started with federal government mandating citizen participation through the Urban Renewal Act of 1954 to a softer language that encouraged citizen participation as seen in various federal policies promulgated in the 1970s. According to Roberts, the federal government's emphasis on including citizens in decision making resulted in a surge of civic engagement requirements in programs at state and local levels of government.

Not long after the impetus to increase citizen participation, Arstein in A Ladder of Citizen Participation (1969) identified eight categories of participation including manipulation, therapy, informing, consultation, placation, partnership, delegated power, and citizen control. She criticized the lower levels of the ladder as being "empty rituals" of participation and praised the higher rungs of the ladder as providing "the real power needed to affect the outcome of the process" (p. 216). The latter conception of public participation according to Roberts (2004) is "direct citizen participation," which he defines as "the process when members of a society (those not holding office or administrative positions in government) share power with public officials in making substantive decisions and in taking actions related to the community" (P. 320). While this definition highlights the importance of power sharing, direct citizen participation also can result in the formation of social capital, which also is deemed a key variable facilitating collective action in planning practice.

Since the term's rise to contemporary usage, social capital has been the subject of rediscovery and redefinition by economists, sociologists, and others (Putnam 2000). In 1986, Pierre Bourdieu, a French philosopher and sociologist, describes social capital as the network of relationship produced by investments strategies "individual or collective, consciously or unconsciously aimed at establishing or reproducing social relationships that are directly usable in the short or long term i.e., at transforming contingent relations, such as those of neighborhood, the workplace or even kinship, into relationships that are at once necessary and elective, implying durable obligations subjectively felt (feelings of gratitude, respect, friendship, etc.) or institutionally guaranteed (rights)" (pp. 249-50). James Coleman, an American sociologist, defines social capital by its function: "It is not a single entity but a variety of entities with two characteristics in common: they all consist of some aspect of social structures and they facilitate certain actions of actors-whether persons or corporate actors-within the structure" (Coleman 1988, S98). A more recent definition put forth by Robert Putnam, defines social capital as the "connections among individuals - social networks and the norms of reciprocity and trustworthiness that arise from them" (Putnam 2000, 19) and "that enable participants to act more effectively to pursue shared objectives" (Putnam 1995, 664-5).
Scholars of social capital tend to agree that social capital is composed of three elements: relationships, trust, and norms. Relationships are the foundations of our social networks and are the interpersonal ties that link individuals to one another. Indirect relationships may include common attributes such as occupation, religion, education, memberships, friendship ties, interests, attendance at events ... (Laumann and Pappi 1976; Heinz et al. 1993). On the other hand, direct relationships are defined a pairwise or one-to-one relationships, which can be measured by the presence or lack of a relationship or pattern of communication such as one-to-one exchanges of information. Similarly, trust can be indirect or direct. When referring to indirect trust, also referred to as generalized trust, scholars assess the level an individual "finds others trustworthy" or "trusts others." An example of direct trust would be the level an individual trusts a specific individual or organization. The final component of social capital, social norms, is defined as the social rules that enable groups to function and may include, for example, accepted codes of conduct, obligation, cooperation, and reciprocity (Bourdieu 1986; Coleman 1988; Putnam 2000).

Accounts of social capital in traditional participatory planning processes typically rely on interviews and case study assessments that have revealed that constituents in face-toface dialogue have formed new relationships and increased trust of other stakeholders (Susskind and Cruikshank 1987; Healey 1997; Wondolleck and Yaffee 2000; Innes and Booher 2003). More recent studies have used quantitative measures to assess the development of trust and relationships. Leach and Sabatier (2005) in a meta-analysis of watershed partnerships evaluated the formation of interpersonal trust and new relationships. The findings suggest that neither trust nor relationships were significant to implementation of watershed restoration projects. Schneider et al. (2003) conducted a comparative assessment of relationships formed in National Estuary Program (NEP) partnerships and other watershed partnerships using social network analysis and found that NEP partnerships formed more robust social networks: spanned more levels of government, included more experts and formed stronger interpersonal ties. Another study by Mandarano (2009) using social network analysis revealed that the structure of interpersonal ties formed through collaboration influenced how resources were exchanged amongst participants. Lubell's (2007) assessment of trust in the domain of agricultural policy revealed that trust is influenced by institutional distance (trust was greater with local than with federal agency representatives) as well as policy interests. Finally, Lubell's (2004) comparative assessment of NEP and non-NEP partnerships revealed that participants in NEP partnerships developed norms that facilitated conflict resolution and cooperation.

Social capital also is deemed an important outcome of collective action as well as a precursor to its success. Researchers have shown that social capital can facilitate information sharing to arrive at mutual understanding leading to conflict resolution, more effective decision making, more efficient coordination, and increased capacity to respond to future 
challenges (Innes et al. 1994; Innes and Booher 1999; Wondolleck and Yaffee 2000). Moreover, Rohe (2004) in an attempt to establish an agreed upon definition of social capital to guide understanding of collective action at the neighborhood scale conceptualizes civic engagement and social capital as self-reinforcing model: civic engagement begets new relationships, new relationships lead to greater trust, and trust leads to effective collective action and then to individual and social benefits, which in turn can lead to continued civic engagement and effective collective action.

\section{The Influence of the Digital Age on Communication}

Today we are living in the information age, the digital age, a period in which digital communications are the backbone of the economy and society. The digital age emerged from advances in communications and information technology in the $1970 \mathrm{~s}$ that facilitated the production and distribution of information and thus, allowed for new forms of organization such as the emergence of a global economy based on information technology networks (Castells 1996). Such globalization has been made possible by technological developments such as the standardization of different Web-based protocols, which has significantly improved the communication and collaboration between communities throughout the world. According to Friedman (2006), outcomes of digital technologies including the new age of creativity (Windows in 1989), connectivity (World Wide Web in 1995), and uploading online materials by users are among the "ten forces that flattened the world."

The impacts of the digital age have spread beyond the economy and are expressed as changes in the urban/regional landscape and social society. Cybercities are conceptually different from traditional large cities, which have businesses clustered so that one business could help others do business following "agglomeration of economies" (LeGates and Stout 2007). In the digital age, information can travel at great speed to anywhere in the world through complex global networks (Castells 1999; Mitchell 2001), which reduce the need for clustering businesses to realize the benefits of working within a comfortable physical proximity. On the other hand, even after the talk about the "death of distance," researchers have argued that place still does matter in this digital age, "whether defined in geographical or electronic terms" (Mosco 2004, 203). The most prominent examples of these places, also known as "global cities" (Sassen, 1991) or "sticky spaces" (Markusen, 1999), include global financial capitals like Manhattan, London, and Tokyo and high-tech industrial districts or "technopoles" (Mosco 2004) like Silicon Valley, Silicon Alley (New York), Bangalore (India), along with many second tier cities. Sassen argues, " ... while the new telecommunications technologies do indeed facilitate geographic dispersal of economic activities without losing system integration, they have also had the effect of strengthening the importance of central coordination and control functions for firms and, even, markets" (Sassen 2004, 196). Connectivity, especially the power of the Internet, does not overshadow the importance of place or geography; it rather creates new important nodes and particular spaces in global networks (Mosco 2004; Zook 2004). At the social level, a study done by Keith Hampton (2004) on a Canadian smart community "Netville" documented that information and communication technologies "support the growth of social networks, social capital and community well-being" (p. 261). According to this research, Internet use by many "Netville" households did not substitute other forms of social contact, including phone calls, neighbor recognition, home visits, and collective action. In fact, those forms of social contact were observed at a lesser rate in households that were not wired. While these technologies have enabling qualities, they also have played an important role in creating inequalities: the digital divide and dual city. Whereas the digital divide refers to the differences in those who have access to computers, the Internet, and other digital technologies and thus, those who can reap their benefits (Selwyn 2004), the dual city refers to a restructuring of the economy into high paying jobs in the hightech industry and low-wage jobs in the nontechnical but supporting service economy (Castells 1989; Mitchell 1999).

With respect to society, the use of information technology has created a new social paradigm, the network society, in which social relationships are based on information technology networks (Castells 1996, 2000). Recent technological developments have created new forms of virtual social networks that are only partially connected to a geographic location, as they exist in cyberspace - the Internet. Access to IT equipment, skills, and jobs has significantly increased the number of individuals using digital technologies on a daily basis. Digital technology is constantly evolving and influencing our online habits (Avenue A 2007). As a result, we build cities in the cyberspace with virtual residents, visitors, squares, cafes, neighborhoods, and ports (Graham 2004, 244). The regular use of Internet and other digital technologies is seen in the proliferation of personal Web sites, blogs, forums, wikis, social and professional networks, and twitter accounts. This has enabled citizens to become virtual participants in happenings around the world with the help of real-time reporting and high-speed video distribution (Gorry 2009). Every citizen with a mobile phone or computer with an Internet connection has the capability to become a citizen journalist, create advocacy groups, organize public gatherings, connect with people across the globe, and accomplish tasks without fact-to-face interaction. In addition, Tweeter, Facebook, LinkedIn, and other online social network platforms provide unprecedented levels of networking. This has demonstrated the phenomenon of Smart Mobs (Rheingold 2003) and the ability of people to rally for local, regional, and global causes. As demonstrated in Pasek, More, and Romer's (2009) research of the relationship between social capital and online use of social network sites such as MySpace and Facebook, for fourteen- to twenty-two-year olds such virtual networks can encourage greater civic engagement, which was measured as participating in a club or other extracurricular activity.

The U.S. 2008 presidential campaign is one of the most current and visible examples of an uptick in civic engagement 
through Internet technologies. The use of online social networks by the Obama presidential campaign as a source of communications was a major innovation transforming the way campaigns exchanged information, recruited volunteers, and raised money (Owen 2009, 24). However, during the recent controversy over a national health care plan, the Obama administration has failed to rally supporters using the same digital social network technologies (The Associated Press 2009). At this point, it is not clear why the use of the same digital social network applications did not rally supporters but the answer may reflect limits in the use of electronic communications technology to encourage civic engagement, a disinterest in the national health care issue, or, perhaps, similar decline in civic engagement experienced during the Great Depression.

\section{Digital Technologies in Planning Practice}

While nearly any new technology can be potentially used to increase citizen participation in planning, there are roughly ten free Internet tools that can be used to support planning practice (Steins 2009). See Table 1 for Web links to how these Webbased tools currently are being used in planning practice. While, policy makers are increasingly using Web-based tools to increase and facilitate community participation, e-government techniques may not be able to solve all the challenges of public participation, but they facilitate reaching out to a broader group of citizens (Evans-Cowley and Conroy 2005).

Another technology that holds promise as a method for increasing government agency communications with citizens and citizen engagement is public participation geographic information systems (PPGIS). PPGIS was originally defined by the National Center for Geographic Information and Analysis (NCGIA), with a goal of bringing the academic practices of GIS and mapping to the local level in order to empower and include marginalized populations, who typically have little voice in the public arena. In general, the various definitions of PPGIS have the same general theme of involving the public in decision making using GIS, but their level of participation and the methods used are not clearly defined. Participants completing a ten-minute Internet survey versus learning GIS software and performing analyses are very different levels of participation. PPGIS is successfully being used in many cities worldwide as a form of e-government and public participation. For example, the Portland Oregon Metro Web site provides various interactive resources for public use including interactive maps that provide the users with the location of the nearest recycling center or allow the user to plan a bike route. In addition, through "build your high capacity system" function, users provided input through the online questionnaire to inform the city's new High Capacity Transit System Plan (Oregon Metro 2010).

\section{Evaluating Digital Social Capital in Planning Practice}

Due to the scarcity of assessments of the influence of the digital public participation methods on building social capital, we preface this section with a review of the impact of Internet technologies on personal communications and social capital to provide a broader context for existing and future research. The earliest and currently, one of the most powerful uses of the Internet is the use of Web sites to provide information. Overtime, usage of the Internet changed allowing users to not only download information but also upload content. The term, "Web 2.0" has come to signify a range of Web development techniques that facilitate information sharing and collaboration on the Web (Christopher 2009). New technologies such as distribution lists, photo directories, and advanced search engine capabilities can support online linkages with others and thus build new forms of social capital (Resnick 2001). Such advances have influenced many aspects of our society, from creating business models to shaping peoples' sense of community.

Studies of social networking sites (SNS) indicate that this digital communication platform has the greatest potential to create social capital. SNS are commonly known as "webbased services that allow individuals to (1) construct a public or semi-public profile within a bounded system, (2) articulate a list of other users with whom they share a connection, and (3) view and traverse their list of connections and those made by others within the system" (Boyd \& Ellison 2007, 211). Since its inception in 1997, there are now hundreds of SNSs such as Facebook, LinkedIn, and so on, around the world. The popularity of SNS is likely due to the fact that this technology enables users to maintain a number of weak ties cheaply and easily, as well as create and maintain larger, diffuse networks of relationships from which they could potentially draw resources (Donath and Boyd 2004; Resnick 2001; Wellman et al. 2001). Surveys of undergraduates at a large university (Ellison, Steinfield, and Lampe 2007; Steinfield et al. 2008) suggest that (1) intense Facebook use is closely related to the formation and maintenance of social capital, (2) social networking is associated with distinct measures of social capital, including bridging and bonding; and (3) self-esteem may operate as a moderator of the relationship between social network site use and social capital. In addition, Ellison, Steinfield, and Lampe (2007) found that the intensity of Facebook use was a significant predictor of bridging social capital, networks consist of larger, less intimate relationships as opposed to tightly knit small groups, and the relationship between Facebook use and bridging social capital was greater for low-self-esteem students than for high-self-esteem students. The latter contradicts the "rich get richer" finding by Kraut et al. (2002), which showed high-extraversion subjects gained more from their Internet use than low-extraversion subjects.

Another aspect of research on Internet use that is relevant to planning practice is the study of the correlation between the type of Internet use and civic life. This line of inquiry seeks to understand if the Internet is a new form of media that distracts individuals from community life similar to the reported (Putnam 2000) adverse impact of the television on civic engagement. Shah, Kwak, and Holdert (2001) conducted a study, a secondary analysis of the 1999 Life Style Study that 


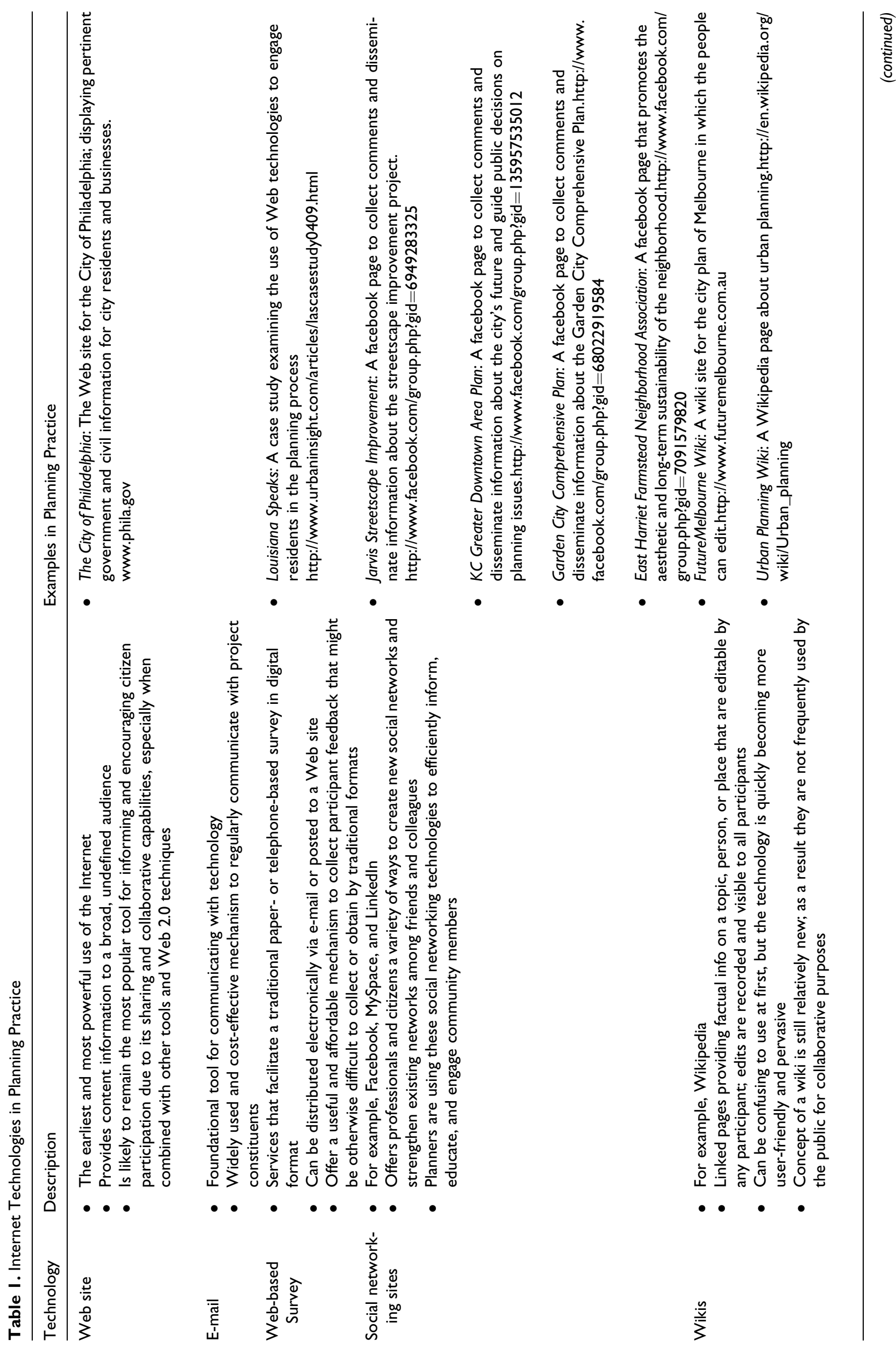




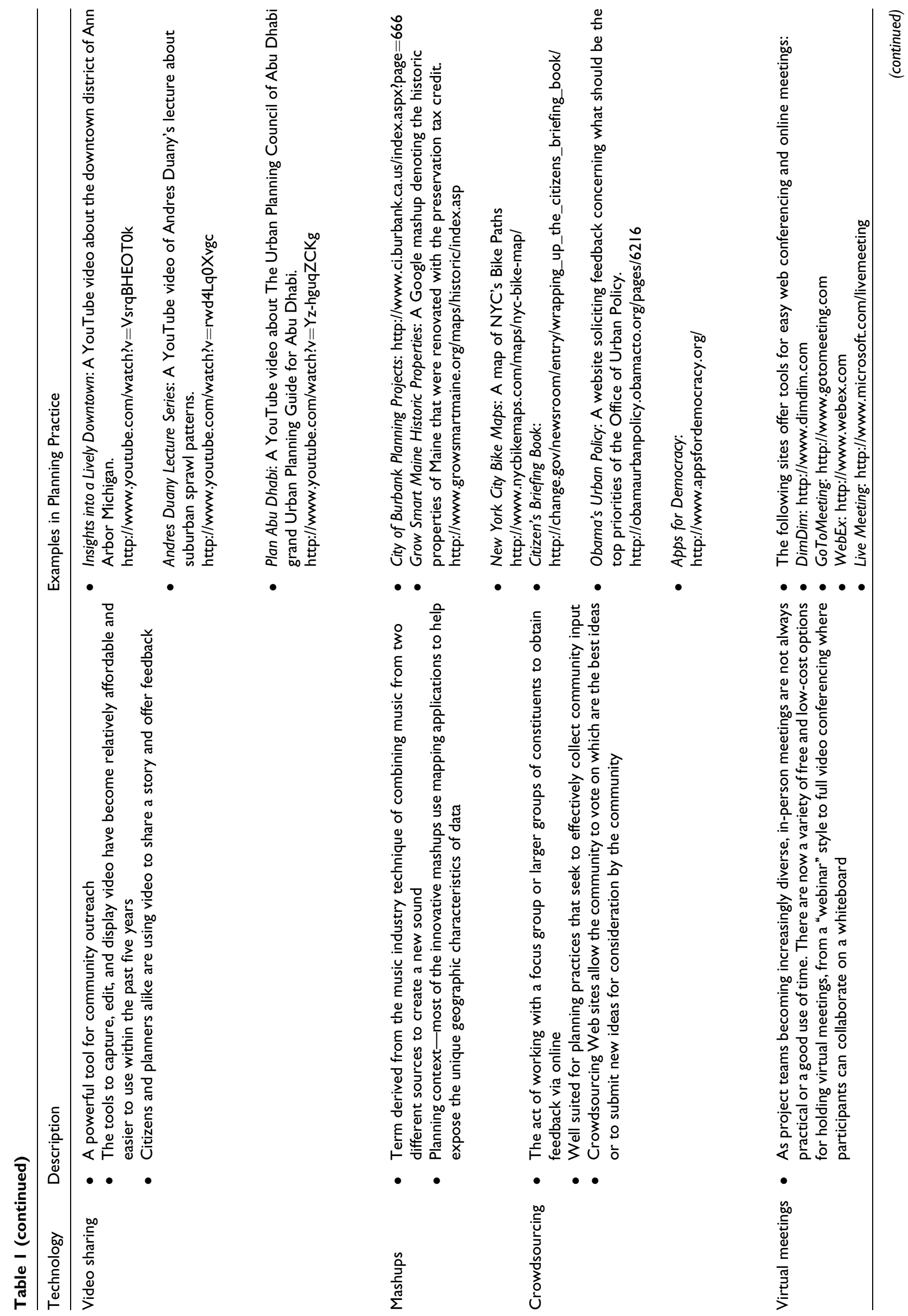




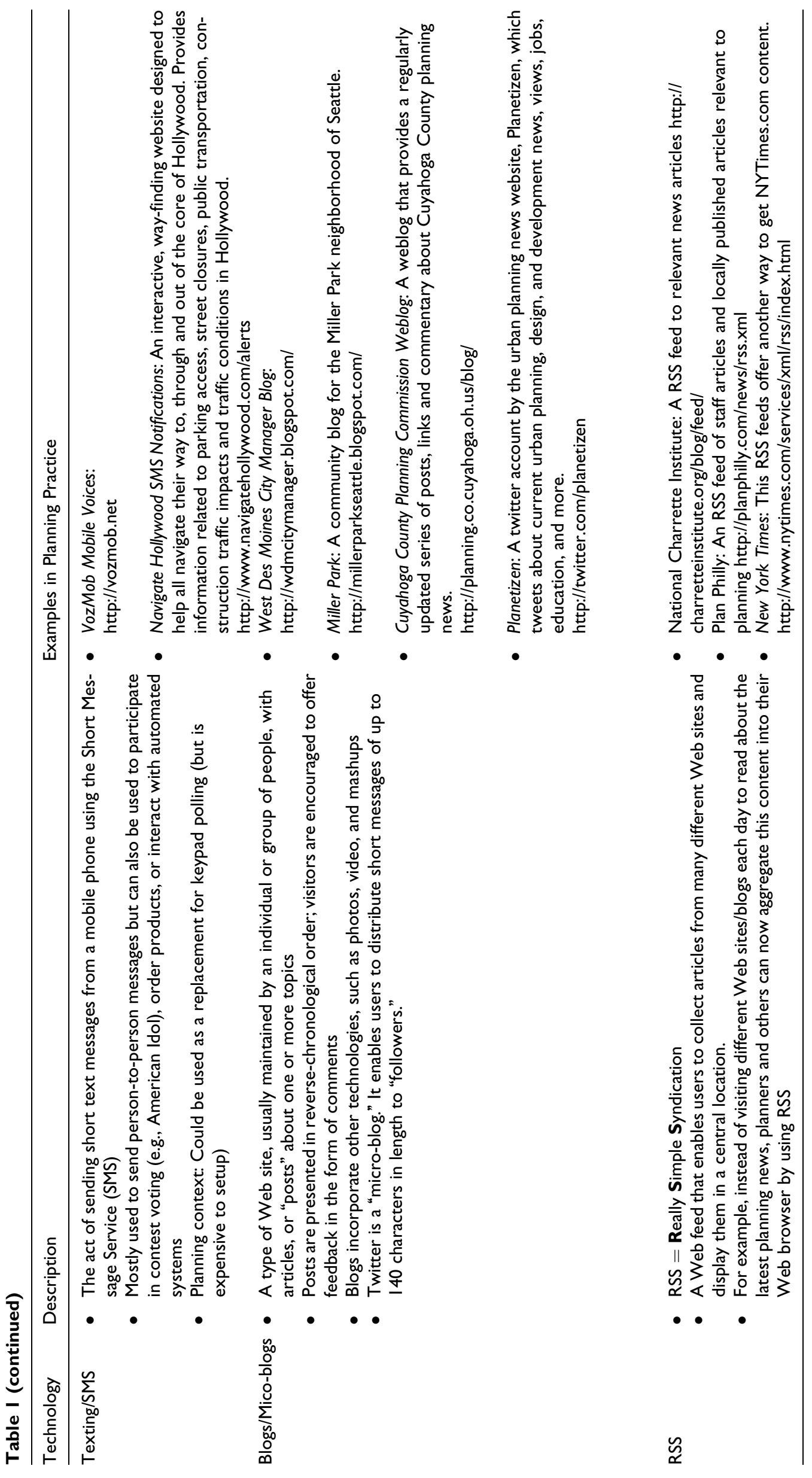


surveyed more than 500,000 Americans, to assess the influence of four types of Internet use on civic life, social trust, and life contentment. Internet use was categorized as social recreation, product consumption, information exchange, and financial management. The study derived a composite indicator for civic life using respondents' frequency of activity in areas such as volunteer work, community projects, club activity, and the like. In addition, trust was measured as generalized trust of others. The findings revealed that Internet use for information exchange was positively correlated with civic life and social trust. In contrast, Internet use for social recreation was negatively related to their engagement in civic activities, trust in other people, and life contentment. These findings hold promise for digital public participation, which for the most part is being used to facilitate and increase the exchange of information between planning organizations and stakeholders.

In the first few years of the twenty-first century, many researchers suggested that information technology would make government decisions and processes more transparent, accountable, and responsive, and thus, e-government would increase citizen communication with government agencies (Ho 2002; Seifert and Peterson 2002; Chadwick and May 2003; Thomas and Streib 2003; West 2004). Not surprisingly, studies show that an increasing number of local governments started improving their transparency by posting contact information, legislation, agendas, and policies in their Web sites (Mossberger and Tolbert 2005). In addition, the Municipal eGovernment Assessment Project (MeGAP) assessed the digital public participation techniques as practiced by the largest U.S. cities. The study found out that the most successful cities had used a number of tools in their Web sites in order to encourage public participation. These included scheduled emeetings, conversation forums, online survey/polls, streaming audio of meetings and hearings, user customization, participation opportunity, listservs, and visualization technologies (Kaylor 2005). Another study of the use of Web-based technologies in more than 500 planning agencies in the United States (Simpson 2005) reveals that while 95 percent of the agencies surveyed have an Internet presence, the agencies are using digital technologies to engage in e-services such as broadcasting information, with less emphasis on citizen interaction.

Lastly, Lowdens, Pratchett, and Stoker (2001) conducted a study of innovations in public participation in all local authorities in England. The survey revealed that while 24 percent claimed to have interactive Web sites, another assessment of local government Web sites found that "no authority in Britain offers a truly transactional website and only 6 percent offer a good level of interaction" (p. 208). This study raises the concern over the reliability of self-reported accounts of the use of digital public participation technologies and suggests the need for empirical research to assess to the extent such practices are improving government transparency, accountability, responsiveness, and interaction with their citizens.

Although there are prime examples of agencies using digital technologies to enhance direct citizen engagement in city and regional planning processes (see Table 2), the existing documentation tends to be descriptive versus analytical and thus, the social outcomes of these efforts have not yet been evaluated. The fact that this is an emerging practice is probably the root cause for this gap in research. While the literature is scant when it comes to evaluations of digital civic engagement in planning practice and social capital, it offers valuable insight into this emerging field of Internet-based public participation.

An evaluation of two PPGIS case studies in the United Kingdom (Carver et al. 2001) provides useful insight into the issues that compound this form of digital civic engagement. The researchers tested the use of PPGIS to engage stakeholders to address environmental problems at two spatial scales using one local and one regional case study in the United Kingdom. The local planning process included a community event during which participants placed markers on a site map, which was then transformed into an interactive Web-based map. This process engaged 126 stakeholders but mostly during the event not online. The regional project involved engaging participants in developing woodland regeneration scenarios for a national park. Users were engaged in public forums during which they accessed the Web-based map to weight their preferences and then to generate planting suitability maps. The regional project engaged over 200 participants. The findings derived largely from observing how users interacted with the Web-based system indicate that PPGIS was deemed useful and popular by its users and that the users had a high degree of spatial awareness. The authors also identify constraints that need to be addressed to improve the feasibility of broader use of digital civic engagement such as "access to the Internet, public understanding of spatial problems, and accountability within the decision-making process" (p. 919). In regards to the latter, the authors claim that " $[\mathrm{a}]$ high degree of trust and transparency needs to be established and maintained within the public realm to give web-based public participatory processes legitimacy and accountability" (p. 919). The limitation of this study is that it did not assess the use of this technology by remote users or whether this form of civic engagement engaged more participants or a different demographic than traditional public participation practices.

Another empirical study conducted by Harrison and Haklay (2002) used focus group feedback to evaluate the use of PPGIS in two planning workshops. Some of the key concerns participants raised were related to the transparency of the agencies criteria for decision making and the users' trust of the information provided to them through the PPGIS platform. The authors claim that PPGIS alone is not sufficient to overcome the broader questions regarding the legitimacy of the planning process and suggest that institutional norms and practices of governance that tend to be highly political and flexible also need to change in order to address these concerns. This study in particular raises a note of caution with respect to our expectations of improving the trust component of social capital through the use of digital civic engagement in planning practice. Again, this study is limited to participant use of PPGIS during onsite workshops and thus does not evaluate the use of PPGIS when accessed remotely. 
Table 2. Examples of Digital Civic Engagement in City and Regional Planning

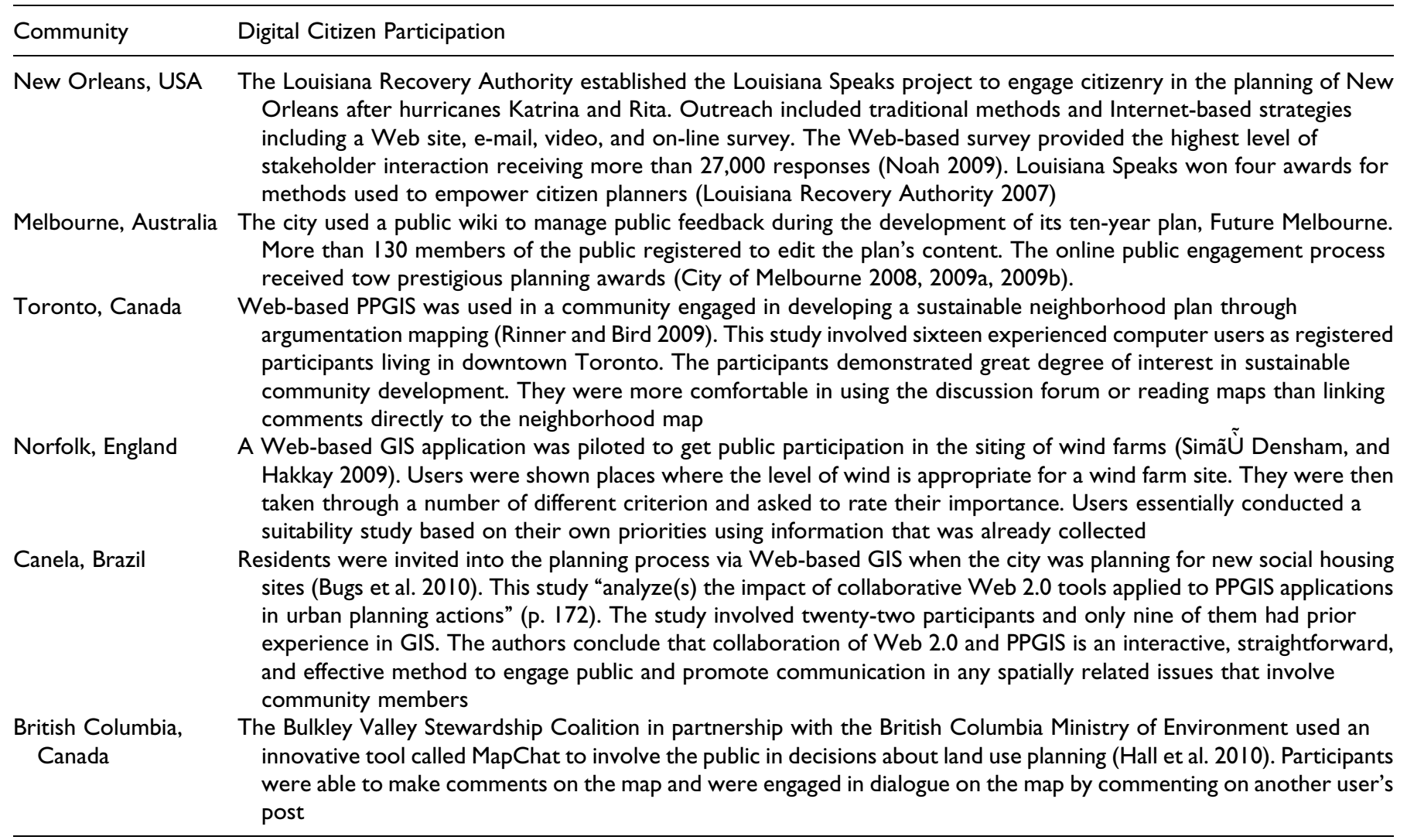

In response to these and other observed limitations of PPGIS (Rinner and Bird 2009), Bugs et al. (2010) developed a prototype PPGIS application that not only enabled participants to have high levels of communication with the system but also to share comments and respond to others' comments much like SNS. This is made possible by storing user comments in a GIS layer, which also facilitate analysis by the host agency. The pilot testing by twenty-two participants in Canela, Brazil indicated that most of the users demand these kinds of communication applications as a way to express their opinions on urban planning, to communicate with other users, and most importantly to communicate "vertically - with decision makers - in a more interactive and straightforward way" (p. 180). These findings suggest that the next generation of PPGIS applications incorporating communication methods based on SNS could make a profound impact on improving agency capacity to develop truly interactive Web sites and increasing the level of digital civic engagement, which holds the promise of producing similar social capital outcomes as observed in the use of traditional SNS. Once again, the research did not include remote access to PPGIS.

More recently, a comparative study of traditional public participation (TPP) and Web-based public participation (WPP) methods by Stern, Ori, and Svoray (2009) falls within the realm of the type of study necessary to understand the impacts of direct digital civic engagement on social capital. The study evaluated involvement, trust, and empowerment of WPP and
TPP methods in a year-long comprehensive planning process for neighborhood revitalization in Tel-Aviv, Israel. Involvement measured both the characteristics of the people engaged and their level of involvement. The data indicate that younger people between their twenties and thirties were those that only participated through WPP. The more educated in their thirties and forties used WPP to complement TPP. Those with higher levels of involvement participated through TPP and WPP. In addition, TPP is found to be more effective than WPP when it comes to empowerment and trust; however, when users used both TPP and WPP, these outcomes were significantly greater. Such findings led the researchers to conclude that "WPP is an effective and affective complementary means for public participation, but it cannot yet replace [TPP]" (p. 1083).

\section{Discussion}

Digital methods are starting to be embraced and lauded as effective tools for citizen participation and other outreach approaches. At this time, assessments of the impacts of digital public participation on social capital are scarce; however, the debates over the impacts of digital technologies in other forms of communication on social capital raise important concerns for consideration by planners. The two sides of the debate are framed by critics claiming virtual relationships are replacing face-to-face relationships and others arguing that these technologies enable broader and more effective social networks (Wellman et al. 
2001). The main criticism against the use of digital media to build social capital is that it primarily remains in the realm of cyberspace. This raises the concern of the usefulness of digital techniques in building effective social capital because, "the unique characteristics of face-to-face communications in building consensus, communicating complex information, or creating new ideas means it cannot be totally replaced by online communications" (Goodspeed 2008).

Other concerns related to the general use of the Internet and digital technologies are relevant to the trust component of social capital and the transparency of e-democracy. For example, the quality of Internet-based media is questioned for its quality, authenticity, bias, and transparency. Andrew Keen, in The Cult of the Amateur: How Today's Internet is Killing our Culture (2007), warns that the tools that hold the promise of "democraticized" media are resulting in "less culture, less reliable news and a chaos of useless information" $(2007,16)$. He introduces the concept of "digital Darwinism"-with all the incessant blogging, wiki-ing and social networking only those that are the loudest and most opinionated survive. Another raised is the issue of transparency. The Internet allows anonymity that provides a veil to hide authorship and whether or not online authors are being paid by sponsors to post unbiased reviews (Arango 2009). These concerns are relevant to the emerging use of digital technologies to enable civic engagement. For example, in a public forum, there is a certain level of transparency that is lost over the Internet. In addition, individuals with strong digital networks can mobilize the voice of likeminded spirits much more quickly than those who are new to using social network sites and thus could potentially sway the results of opinion polls or other modes of civic engagement to collect public opinion. Finally, the study by Bugs et al. (2010) concludes that although the next generation of PPGIS with SNS user communication capabilities will facilitate exchanges among users and with government agencies, the issue of trust (e.g., trust of other users and trust of how the information will be used) and reputation remain to be addressed.

\section{Conclusion}

Although still in its infancy, planners are beginning to use digital technologies to facilitate direct civic engagement. Traditional methods of public engagement require extensive commitments from individual citizens to understand, track, and provide feedback throughout a planning process. The constituents would need to be physically present at public meetings and to make an effort to remain up-to-date as the process unfolds. Today, as planners increasingly use Internet-based technologies to distribute information about the planning process and to make information available $24 / 7$, it is much easier for a constituent to follow and to engage in the process. Additionally, as more cities enable the use of interactive technologies (wikis, email, Web feedback, etc.), constituents who previously were unable to participate in time-intensive and geography-specific activities, now can participate from remote locations and when convenient. The next generation of PPGIS applications with SNS communication capabilities envisioned by Bugs et al. (2010) will increase the level of information exchange and communication of opinions, interests, priorities, and the like among users and with decision makers. The study by Shah, Kwak, and Holdert (2001) indicating that Internet use specifically for information exchange correlates positively with engagement in civic activities and social trust as well as the study of SNS that correlates use of these sites with building social capital hold promise that the use of digital technologies to facilitate and increase public participation will lead to increased public participation and social capital.

On the other hand, there are important issues to consider when designing digital methods for direct civic engagement in planning processes. These concerns include for example whether Internet-based methods of communication reach a broader audience, which is of particular concern for poorer populations that may not have access to a computer or the Internet. This reflects one of the key concerns raised by Carver et al. (2001) in their assessment of PPGIS in the United Kingdom. Yet, they claim that the continued proliferation of the Internet as a communication medium and the advent of the digital television, which precludes the need for a computer, may eradicate this concern. In the interim, planners may need to double their efforts to engage typically disenfranchised populations.

While evaluations of how digital technologies are being used in planning practice as a forum for direct citizen engagement and its impact on social capital is scant, it is important to note that the use of digital public participation is rapidly growing. The comparative WPP-TPP research conducted by Stern, Ori, and Svoray (2009) represents the type of study necessary to understand the impacts of digital civic engagement on social capital. This study is the first to assess whether there are differences in online participation and traditional civic engagement practices with respect to rates of participation and representation, which is fundamental to understanding the role of digital technologies in enhancing civic engagement and social capital. In addition, research is needed to determine if digital public participation processes differ from traditional public participation processes in terms of building the three key components of social capital: relationships, trust, and social norms. Other lines of inquiry include assessments of (1) where the public participation process fits with respect to the ladder of citizen participation (Arnstein 1996), (2) how online feedback is analyzed and by whom, and (3) how effectively online input is incorporated into final plans. Finally, assessments are necessary to understand the implications of digital public participation and its effects on long-term social capital-is the social capital fleeting, lasting, or transferrable to other venues after the call for public participation ends.

\section{Declaration of Conflicting Interests}

The author(s) declared no potential conflicts of interests with respect to the authorship and/or publication of this article. 


\section{Funding}

The author(s) received no financial support for the research and/or authorship of this article.

\section{References}

Arango, Tim. 2009. Soon, bloggers must give full disclosure. The New York Times. Business Section. October 5, 2009.

Arnstein, Sherry. 1996. A ladd of citizen participation. Journal of the American Planning Association 35:216-24.

Avenue A Razorfish. 2007. Digital consumer behavior study. http:// www.razorfish.com/reports/Dig.ConsStudy.pdf (accessed September 3, 2009).

Bourdieu, Pierre. 1986. The forms of social capital. In Handbook of theory and research for the sociology of education, ed. J. Richardson, 241-258. Westport, CT: Greenwood Press.

Boyd, D. M., and N. Ellison. 2007. Social network sites: Definition, history, and scholarship. Journal of Computer-Mediated Communication 13:210-30.

Bugs, Geisa, Carlos Granell, Oscar Fonts, Joaquín Huerta, and Marco Painho. 2010. An assessment of public participation GIS and Web 2.0 technologies in urban planning practice in Canela, Brazil. Cities 27:172-81.

Carver, Steve, Andrew Evans, Richard Kingston, and Ian Turton. 2001. Public participation, GIS and cyberdemocracy: Evaluating on-line spatial decision support systems. Environmental and Planning B: Planning and Design 28:907-21.

Castells, Manuel. 1989. The informational city: Information technology, economic restructuring and the urban-regional process. Oxford, UK: Blackwell Publishers.

. 1996. The rise of the network society. Cambridge, MA: Blackwell Publishers.

1999. European cities, the informational society, and the global economy. New Left Review 204:18-32.

2000. Toward a sociology of the network society. Contemporary Sociology 29:693-9.

Chadwick, A., and C. May. 2003. Interaction between states and citizens in the age of the Internet: Egovernment in the United States, Britain, and the European Union. Governance: An International Journal of Policy, Administration, and Institutions 16:271-300.

Christopher, L. Carol. 2007. "Understanding Web 2.0." Seybold Report: analyzing publishing technologies 7.11, June 14, 2007. https://libproxy.temple.edu:2343/login?url=http://search.

ebscohost.com/login.aspx?

direct $=$ true $\& \mathrm{db}=$ aph $\& \mathrm{AN}=25485536 \&$ site $=$ ehost?

live $\&$ scope $=$ site (accessed August 13, 2009).

City of Melbourne. 2008. Media release: City of Melbourne takes home prestigious planning award. September 20, 2008. http:// www.futuremelbourne.com.au/wiki/view/FMPlan/PlanningAward (accessed October 13, 2009).

- 2009a. Media release: City of Melbourne \& City of Sydney Share Major Planning Award, October 31, 2009. http:// www.futuremelbourne.com.au/wiki/view/FMPlan/ PresidentsAward (accessed October 13, 2009).

- 2009b. Future Melbourne Wiki Post Implementation Review. City of Melbourne. http://www.futuremelbourne.com.
au/wiki/pub/FMPlan/WebHome/Future_Melbourne_Wiki_Post_ Implementation_.pdf (accessed September 14, 2009).

Coleman, James S. 1988. Social capital and the creation of human capital. American Journal of Sociology 94:S95-120.

Donath, J. S., and D. Boyd. 2004. Public displays of connection. BT Technology Journal 22:71.

Ellison, N., C. Steinfield, and C. Lampe. 2007. The benefits of Facebook "friends:" Social capital and college students' use of online social network sites. Journal of Computer-Mediated Communication 12:1143-68. http://jcmc.indiana.edu/vol12/issue4/ellison. html (accessed August 13, 2009).

Evans-Cowley, Jennifer, and Maria Manta Conroy, eds. 2005. E-Government and planning: Key citizen participation issues and applications. Columbus, OH: John Glenn Institute for Public Service and Public Policy. http://hdl.handle.net/1811/519 (accessed October 5, 2010).

Friedman, Thomas L. 2006. The world is flat: A brief history of the twenty-first century. New York: Farrar, Straus and Giroux.

Goodspeed, Robert C. 2008. The Internet as a participation tool. The Goodspeed Update. http://goodspeedupdate.com/2008/2225 (accessed October 15, 2009).

Gorry, Anthony, G. 2009. The New Atlantis, Number 24, Spring 2009, pp. 116-120.

Graham, Stephen. 2004. The cybercities reader. New York: Routledge. Hall, G. Brent, Raymond Chipeniuk, Robert D. Feick, Michael G. Leahy, and Vivien Deparday. 2010. Community-based production of geographic information using open source software and Web 2.0. International Journal of Geographical Information Science 24:761-81

Hampton, Keith. 2004. Netville: Community on and offline in a wired suburb. In The cybercities reader, ed. S. Graham, 256-62. New York: Routledge.

Harrison, Carolyn, and Mordechai Haklay. 2002. The potential of public geographic systems in UK environmental planning: Appraisals by active publics. Journal of Environmental Planning and Management 45:841-63.

Healey, Patsy. 1997. Collaborative planning. London: Macmillan Press.

Heinz, John P., Edward O. Laumann, Robert L. Nelson, and Robert H. Salisbury. 1993. The hollow core. Private interests in national policy making. Cambridge: Harvard University Press.

Ho, A. T.-K. 2002. Reinventing local governments and the e-government initiative. Public Administration Review 62:434-44.

Innes, Judith E., and David E. Booher. 1999. Consensus building and complex adaptive systems. A framework for evaluating collaborative planning. Journal of the American Planning Association 65:412-23.

. 2003. The impact of collaborative planning on governance capacity. Berkeley: Institute of Urban and Regional Development.

Innes, Judith, Judith Gruber, Michael Neuman, and Robert Thompson. 1994. Coordinating growth and environmental management through consensus building. California Policy Seminar. Berkeley, CA: University of California, Berkeley.

Kaylor, Charles. 2005. The state of local e-government and e-democracy: Benchmarking the progress of US cities at providing online opportunities for citizen engagement. In E-government and 
planning: Key citizen participation issues and applications, ed. Jennifer Evans-Cowley and Maria Manta Conroy, 4-15. Columbus, OH: John Glenn Institute for Public Service and Public Policy. http://hdl.handle.net/1811/519 (accessed, October 5, 2010).

Keen, Andrew. 2007. The cult of the amateur: How today's Internet is killing our culture. New York: Broadway Business.

Kraut, R., S. Kiesler, B. Boneva, J. Cummings, V. Helgeson, and A. Crawford. 2002. Internet paradox revisited. Journal of Social Issues 58:49-74.

Laumann, Edward O., and Franz U. Pappi. 1976. Networks of collective action. New York: Academic Press.

Leach, William D., and Paul A. Sabatier. 2005. Are trust and social capital the keys to success? Watershed partnerships in California and Washington. In Swimming upstream. collaborative approaches to watershed management, ed. Paul A. Sabatier, Will Focht, Mark Lubell, Zev Trachtenberg, Arnold Vedlitz, and Marty Matlock, 233-58. Cambridge, MA: The MIT Press.

LeGates, Richard, and Frederic Stout. 2007. Introduction to "The impact of the new technologies and globalization on cities". The City Reader, 4th ed. London and New York: Routledge.

Louisiana Recovery Authority. 2007. Media release: Louisiana speaks hits grand slam at state APA planning awards, September 21, 2007. http://lra.louisiana.gov/index.cfm?

$\mathrm{md}=$ newsroom $\& \mathrm{tmp}=$ detail $\&$ articleID $=131$ (accessed October 13, 2009).

Lowdens, Vivien, Lawrence Pratchett, and Gerry Stoker. 2001. Trends in public participation: Part 1-Local government perspectives. Public Administration 79:205-22.

Lubell, Mark. 2004. Resolving Conflict and Building Cooperation in the National Estuary Program. Environmental Management 33(5): 677-691.

Lubell, Mark. 2007. Familiarity breeds trust: Collective action in a policy domain. Journal of Politics 29:237-50.

Mandarano, Lynn. 2009. Social network analysis of social capital in collaborative planning. Society and Natural Resources 22:245-60.

Markusen, Ann. 1999. Sticky places in slippery space: A typology of industrial districts. In The new industrial geography, ed. T. Barnes and M. Gertler, 98-123. London: Routledge.

Mitchell, William J. 1999. E-topia. Cambridge: Massachusetts Institute of Technology Press.

- 2001. E-topia: Urban life, Jim-But not as we know it. Cambridge: MIT Press.

Mosco, Vincent. 2004. Webs of myth and power: Connectivity and the new computer technolpolis. In The cybercities reader, ed. S. Graham, 199-204. New York: Routledge.

Mossberger, Karen, and Caroline Tolbert. 2005. Improving the citizen-government connection through technology? In E-government and planning: Key citizen participation issues and applications, ed. Jennifer Evans-Cowley and Maria Manta Conroy, 38-47. Columbus, OH: John Glenn Institute for Public Service and Public Policy. http://hdl.handle.net/1811/519 (accessed, October 5, 2010).

Noah, Josie. 2009. Louisiana speaks: A case study examining the use of web technologies to engage residents in the planning process. http://www.urbaninsight.com/articles/lascasestudy0409.html (accessed September 14, 2009).
Oregon Metro. 2010. Oregon Metro web site. http://www.oregonmetro. gov/index.cfm/go/by.web/id=29903 (accessed July 15, 2010).

Owen, Diana. 2009. The campaign and the media. In The American elections 2008, ed. Jamet M. Box-Steffensmeier and Steven E. Schier, 9-31. Lanham, MD: Rowman \& Littlefield Publishers.

Pasek, Josh, Eian More, and Daniel Romer. 2009. Realizing the social Internet? Online social networking meets offline civic engagement. Journal of Information Technology \& Politics 6:197-215. http://stanford.academia.edu/JoshPasek/Papers/97409/Realizing the_Social_Internet_Online_Social_Networking_Meets_Of\%EF\% AC\%82ine_Social_Capital (accessed August 13, 2009).

Putnam, Robert. 1995. Tuning in tuning out: The strange disappearance of social capital in American. Political Science and Politics 28:664-83.

2000. Bowling alone. The collapse and revival of American community. New York: Simon \& Schuster.

Resnick, P. 2001. Beyond bowling together: Sociotechnical capital. In HCI in the new millennium, ed. J. Carroll 647-72. New York: Addison-Wesley.

Rheingold, Howard. 2003. Online lecture at MIT_Smart Mobs: The next social revolution, November 13, 2003. http://mitworld.mit. edu/video/22/ and http://www.smartmobs.com/ (accessed August 13, 2009).

Rinner, C., and M. Bird. 2009. Evaluating community engagement through argumentation maps - A public participation GIS case study. Environment \& Planning B: Planning \& Design 36:588-601.

Roberts, Nancy. 2004. Public deliberation in an age of direct citizen participation. American Review of Public Administration 34:325-53.

Rohe, William M. 2004. Building social capital through community development. Journal of the American Planning Association 70:158-64.

Sassen, Saskia. 1991. The global city. Princeton, NJ: Princeton University Press.

. 2004. Agglomeration in the digital era? In The cybercities reader, ed. S. Graham, 195-98. New York: Routledge.

Selwyn, Neil. 2004. Reconsidering the political and popular understandings of the digital divide. New Media \& Society 6:341-62.

Shah, Dhavan, Nojin Kwak, and R. Lance Holdert. 2001. "Connecting" and "Disconnecting" with civic life: Patterns of Internet use and the production of social capital. Political Communication 18:141-62.

Seifert, J., and E. Peterson. 2002. The promise of all things E? Expectations and challenges of emergent electronic government. Perspectives on Global Development and Technology 1:193-212.

Simãoa, Ana, Paul J. Densham, and Mordechai (Muki) Haklay. 2009. Web-based GIS for collaborative planning and public participation: An application to the strategic planning of wind farm sites. Journal of Environmental Management 90:2027-40.

Simpson, David. 2005. Use of web technology by U.S. Planning Agencies: Results from a National Benchmarking Survey. Excerpt from the Municipal Yearbook. www.urbaninsight.com (accessed July 21, 2010).

Schneider, Mark, John Scholz, Mark Lubell, Denisa Mindruta, and Matthew Edwardsen. 2003. Building Consensual Institutions: 
Networks and the National Estuary Program. American Journal of Political Science 47(1):143-158.

Steinfield, Charles, Nicole B. Ellison, and Cliff Lampe. 2008. Social capital, self-esteem, and use of online social network sites: A longitudinal analysis. Journal of Applied Developmental Psychology 29:434-45.

Steins, Chris. 2009. Top 10 free web applications for planning. Planetizen. http://www.planetizen.com/node/38952 (accessed September 14, 2009).

Stern, Eliahu, Gudes Ori, and Tal Svoray. 2009. Web-based and traditional public participation in comprehensive planning: A comparative study. Environment and Planning B: Planning and Design 36:1067-85.

Susskind, Lawrence, and J. Cruikshank. 1987. Breaking the impasse. Consensual approaches to resolving public disputes. New York: Basic Books.

Taylor, Nigel. 1998. Urban Planning Theory since 1945. London, UK: Sage.

The Associated Press. 2009. Young Obama backers AWOL from health care fight. New York Times, August 24, 1.

Thomas. J. C., and G. Streib. 2003. The new face of government: Citizen-initiated contacts in the era of egovernment. Journal of Public Administration Research and Theory 13:83-102.

Wellman, Barry, Anabel Quan Haase, James Witte, and Keith Hampton. 2001. Does the Internet increase, decrease or supplement social capital? American Behavioral Scientist 45:436-55.

West, D. M. 2004. E-government and the transformation of service delivery and citizen attitudes. Public Administration Review 64:15-27.
Wondolleck, Julia M., and Steven L. Yaffee. 2000. Making collaboration work. Lessons from innovation in natural resource management. Washington, DC: Island Press.

Zook, Matthew. 2004. Cyberspace and local places: The urban dominance of Dot.Com geography in the late 1990s. In The cybercities reader, ed. S. Graham, 205-11. New York: Routledge.

\section{Bios}

Lynn Mandarano is an assistant professor at the Department of Community and Regional Planning and Research Fellow at the Center of Sustainable Communities at Temple University. She teaches undergraduate and graduate courses in Sustainable Community Design and Development, Collaborative Planning, Studio, Analytical Methods and Infrastructure Planning and Management.

Mahbubur Meenar has spent the last decade developing applications of GIS and other technologies to urban and regional analysis. He is the Assistant Director of the Center for Sustainable Communities at Temple University and adjunct faculty at the Department of Community and Regional Planning.

Christopher Steins is the chief executive officer of Urban Insight, a technology consulting firm focused on using technology to support planning and citizen participation. He is also the co-founder and coeditor of Planetizen (www.planetizen.com), and is a lecturer at the University of Southern California's School of Policy, Planning and Development. 